\title{
Role of Leaf Litter in Above-Ground Wood Decay
}

\author{
Grant T. Kirker ${ }^{1, *(\mathbb{D}}$, Amy Bishell ${ }^{1}$, Jed Cappellazzi ${ }^{2}{ }^{\circ}$, Jonathan Palmer ${ }^{3,+}$, Nathan Bechle ${ }^{1}$, \\ Patricia Lebow ${ }^{1}$ and Stan Lebow ${ }^{1}$ \\ 1 USDA-FS Forest Products Laboratory, Madison, WI 53726, USA; amy.b.bishell@usda.gov (A.B.); \\ nathan.bechle@usda.gov (N.B.); patricia.k.lebow@usda.gov (P.L.); stan.lebow@usda.gov (S.L.) \\ 2 Dept. of Wood Science and Engineering, Oregon State University, Corvallis, OR 97731, USA; \\ Jed.Cappellazzi@oregonstate.edu \\ 3 Northern Research Station, USDA Forest Service, Madison, WI 53726, USA; palmer.jona@gmail.com \\ * Correspondence: grant.kirker@usda.gov; Tel.: +1-608-231-9256 \\ † Current address: 2625 Middlefield Rd \#600, Palo Alto, CA 94306, USA.
}

Received: 17 April 2020; Accepted: 7 May 2020; Published: 9 May 2020

\begin{abstract}
The effects of leaf litter on moisture content and fungal decay development in above-ground wood specimens were assessed. Untreated southern pine specimens were exposed with or without leaf litter contact. Two types of leaf litter were evaluated; aged (decomposed) and young (early stages of decomposition). The moisture content of specimens was monitored, and specimens were periodically removed for visual evaluation of decay development. In addition, amplicon-based sequencing analysis of specimens and associated leaf litter was conducted at two time points. Contact with either type of leaf litter resulted in consistently higher moisture contents than those not in contact with leaf litter. Visually, evident decay developed most rapidly in specimens in contact with the aged leaf litter. Analysis of amplicon-based sequencing revealed that leaf litter contributes a significant amount of the available wood decay fungal community with similar communities found in the litter exposed wood and litter itself, but dissimilar community profiles from unexposed wood. Dominant species and guild composition shifted over time, beginning initially with more leaf saprophytes (ascomycetes) and over time shifting to more wood rotting fungi (basidiomycetes). These results highlight the importance of the contributions of leaf litter to fungal colonization and subsequent decay hazard for above-ground wood.
\end{abstract}

Keywords: wood decay fungi; saprophytic fungi; above-ground exposure; leaf litter; moisture content; amplicon-based sequencing

\section{Introduction}

Soil contact presents a severe deterioration hazard for wood products, but the greatest volume of wood products used outdoors is not in direct contact with the ground. In the last decade, there has been increasing interest in using less toxic preservative systems or lower preservative retentions for wood used above-ground. These preservative formulations may not be evaluated with ground-contact stake tests, and instead are evaluated using above-ground test methods. There are several standardized above-ground test methods [1], but accelerated evaluation of wood products intended for use above-ground has proven more difficult than ground contact evaluations. It remains unclear how well above-ground tests characterize the hazard, or if they actually accelerate the rate of decay relative to in-service applications. Most methods utilize some type of joint, connection, or layering in an effort to trap moisture, but this effect can be undermined using specimens with small dimensions. Although the smaller dimensions do allow more rapid detection of decay once it is present, smaller specimens dry more rapidly than dimensional lumber. In addition, none of the commonly used test methods simulate the accumulation of decaying organic debris that often occurs in connections of treated wood 
used above-ground [2]. Specimens are typically exposed in open areas to remove variability associated with natural shading, and when organic debris (leaf litter) does accumulate, it is removed during periodic inspections. In contrast, accumulation and decomposition of leaf litter is commonly observed in wooden structures, and it is possible that the presence of this decomposing organic matter increases the decay hazard to the adjacent wood product.

Tree cover has been identified as a major factor in understory biodeterioration and nutrient cycling in forest ecosystems [3-7] and leaf litter has been theorized to play a role in the rate of decomposition of coarse woody debris [8-10]. Although not previously reported, the same concepts could theoretically apply for residential wood structures located under the canopy of surrounding trees. It is possible that accumulation and persistence of leaf litter on the surface of residential above-ground structures can serve as both an inoculum source and a potential incubator for future fungal colonizers of the wood in contact [11]. Decomposing leaf litter may contribute to an increased decay hazard in at least two ways. Inadequate moisture is typically a limiting factor in fungal colonization of wood used above-ground [12-14] and is probable that the presence of the leaf litter slows drying of adjacent wood after rain events, thus increasing the proportion of time that the wood moisture content is conducive to decay. It is also possible that decomposing leaf litter plays a role, like soil, in providing a ready supply of nutrients and moisture that facilitates growth and sporulation of decay fungi [15-17]. The latter scenario is especially problematic because it suggests that preservatives evaluated for above-ground efficacy may need to provide protection in a broad spectrum of conditions, some of which are more similar to ground contact than currently assumed.

Although previous research has not directly evaluated the role of leaf litter in the decomposition of wood used above-ground, there have been reports of overlap between fungal groups associated with litter decomposition and wood decay [18]. Researchers evaluating the ability of leaf litter-degrading fungi to also degrade wood reported that many of the isolates caused some degree of weight loss in wood, although generally not to the extent caused by fungi traditionally associated with wood decay [19]. Hammel [20] notes that a succession of bacteria and fungi are thought to decompose leaf litter, with Basidiomycete fungi playing a role in lignin decomposition. Schneider et al. [21] also reported that, although more Ascomycetes were detected overall in leaf litter, Basidiomycetes did appear later in the degradation process, presumably because they were able to decompose remaining lignin compounds. It is thought that the Basidiomycete fungi that degrade leaf litter are more likely to be white than brown rot fungi, but this supposition has not been confirmed by research [20]. However, this white rot premise was circumstantially supported by a study which reported the Basidiomycete fungi found to be degrading leaf litter also caused the litter to have a bleached appearance [22]. Other researchers have reported a lack of Basidiomycetes, but those studies involved leaf litter in early stages of decomposition [23,24].

The available tools to characterize and observe fungal communities have increased dramatically in the last two decades. The development of next generation sequencing technologies has enabled large scale community level analysis and the resulting metagenomic capabilities allow researchers to analyze mixed microbial communities of interest and observe inter and intraspecific interactions [25-27]. Targeted microbial metagenomics, also referred to as metabarcoding or amplicon-based sequencing, is an extremely useful tool for dissecting complex and dynamic microbial communities that have been applied to forest soils [28-30], decaying wood [31,32], and standing trees [33].

The application of next generation sequencing (NGS) technology to characterize leaf litter is well represented in the literature, with less attention having been paid to processed lumber and the residential built environment. For example, Purahong et al. [34] reported dynamic shifts in fungal community composition as leaf litter ages/decomposes, where a general shift occurs from ascomycetous fungi to basidiomycetous fungi as the quality and composition of the leaf litter changes, which has also been reported by Zhang et al. [35]. Differences have been noted between the effects of litter in deciduous and evergreen forests [36], where plant diversity and litter biomass are key drivers in deciduous forest, but host effects outweigh these in evergreen forests. The impacts of global warming 
have also been studied using NGS paired with enzymatic assays [37] and the results of this and other studies found that decomposition rates did not accelerate with increasing temperature, but instead led to an increase in residual lignin paired with an increase of lignin degrading enzymes and increased presence of ectomycorrhizal fungi. The concept of home field advantage (HFA) is one that has garnered considerable interest in recent years [7,38,39], which states that plant biomass is more readily broken down in its native environment than a foreign one. This concept has not been tested in deterioration rates of processed lumber but would suggest that softwood species might degrade faster located in a predominant conifer overstory due to the prevalence of microbes adapted to breaking down the structural components of softwoods. This area represents a critical gap in our knowledge of wood decay in above-ground residential conditions and potentially challenges the current approach to wood protection.

An improved understanding of factors that affect the severity of above-ground decay hazards is critical to the development and evaluation of durable wood products. It is plausible that the presence of leaf litter may heighten the decay hazard for wood used above-ground by increasing wood moisture and/or serving as an inoculum source for wood decay fungi. The objective of this study was to increase our understanding of how decomposing organic matter contributes to decay in above-ground wood structures. In this study, we assessed the characteristics of young and aged litter types, their contribution to wood moisture content and decay, and utilized amplicon-based sequencing to identify and characterize the fungi found within young and aged leaf litter and adjacent to wood in an effort to compare the fungal communities of the leafy substrate to those which successfully colonize and ultimately degrade the wood.

\section{Materials and Methods}

\subsection{Leaf Litter}

The detritus that accumulates on above-ground structures could have a wide range of sources and characteristics depending on the type and proximity adjacent trees and shrubs [40], and one of the challenges of this study was selecting a characteristic or representative material. Two types of leaf litter were investigated, "aged" and "young". The "aged" litter was a commercial product (Hsu organic STA Certified Leaf Compost) prepared in Wausau, Wisconsin, USA and available at garden centers in the Midwest. It has been composted for use as a soil amendment and has an appearance like coffee grounds. Product literature states that it is made from "tree leaves collected in the pristine woodlands of Wisconsin" (https://www.hsugrowingsupply.com/leaf-compost/hsu-leaf-compost). A compost analysis report was provided by the manufacturer (Table 1).

Table 1. Characteristics of the two types of leaf litter evaluated. Nutrient analysis conducted by A \& L

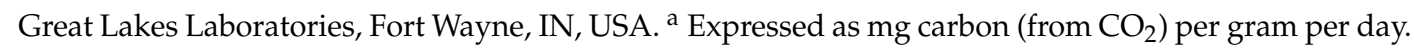
$\mathrm{TS}=$ total solids, $\mathrm{OM}=$ organic matter. ${ }^{\mathrm{b}}$ Respiration may have been reduced by earlier autoclaving and subsequent dry storage.

\begin{tabular}{|c|c|c|}
\hline Litter Characteristic & Aged & Young \\
\hline Nitrogen $(\%)$ & 1.78 & 1.63 \\
\hline Phosphorous (\%) & 0.09 & 0.17 \\
\hline Potassium (\%) & 0.26 & 0.51 \\
\hline Magnesium (\%) & 0.5 & 0.51 \\
\hline Calcium (\%) & 1.78 & 3.5 \\
\hline $\mathrm{pH}$ & 7.9 & 6.5 \\
\hline Organic matter (\%) & 48.58 & 81.84 \\
\hline Organic carbon (\%) & 24.29 & 40.92 \\
\hline Carbon: Nitrogen $(\mathrm{C} / \mathrm{N})$ ratio & 13.6:1 & $25.1: 1$ \\
\hline Germination emergence (\%) & 90 & 100 \\
\hline Germination vigor (\%) & 71 & 15 \\
\hline Respiration, TS ${ }^{a}$ & 1 & $5^{b}$ \\
\hline Respiration, $\mathrm{OM}^{\mathrm{a}}$ & 1 & $1^{b}$ \\
\hline
\end{tabular}


The other type of litter (young) was created from leaves (silver maple, sugar maple, elm, and white oak) that had been loosely piled outdoors for approximately 18 months in the Madison, Wisconsin area. The leaves were dried and then crushed to pass through a $6 \mathrm{~mm}(0.25 \mathrm{in}$.) screen. The intent of the young leaf litter was to evaluate the effect of litter in an earlier stage of decomposition than the commercial leaf litter. A compost analysis of the young leaf litter was conducted by the same laboratory that evaluated the commercial aged litter. The relatively high organic content, and the high carbon: nitrogen ratio and poor germination vigor are indicators that the young leaf litter had undergone less decomposition than the aged litter. Respiration was relatively low for the young leaf litter, but this is probably a function of the initial sterilization and subsequent dry storage prior to analysis. In contrast, the aged leaf litter had undergone compost analysis by the manufacturer prior to sterilization.

\subsection{Treatment Groups Evaluated}

Southern pine sapwood specimens were exposed under five conditions. One condition was without any preservative treatment and without leaf litter contact (Table 2). Comparison untreated specimens were exposed when placed in direct contact with either the aged or young leaf litter. In addition, preservative-treated specimens were exposed either with or without aged leaf litter contact. In this paper, discussion of the preservative-treated specimens is limited to the moisture content and decay evaluations.

Table 2. Treatment groupings used for field studies and subsequent analyses in this study.

\begin{tabular}{ccc}
\hline Group & Treatment & Time (mos) \\
\hline 1 & No Litter & 25 \\
2 & Aged Litter & 25 \\
3 & Young Litter & 25 \\
4 & No Litter & 41 \\
5 & Aged Litter & 41 \\
6 & Young Litter & 41 \\
\hline
\end{tabular}

\subsection{Specimen Preparation and Exposure}

All specimens were cut from southern pine (Pinus taeda L.) 38 by $89 \mathrm{~mm}$ ( 2 by 4 nominal) dimension lumber. The specimens were end-matched to minimize differences in moisture content and decay susceptibility associated with wood variability. One type of each specimen was cut from each of 5 "parent" boards ( $n=25$, specimens total, or 5 per treatment group). The lumber used for the untreated specimens was selected to be free of heartwood and other obvious defects. The preservative-treated specimens were cut from lumber that had been commercially pressure-treated with particulate copper azole at the target retention intended for above-ground use. Prior to exposure, all specimens were conditioned to uniform weight in a room maintained at $23^{\circ} \mathrm{C}$ and $55 \% \mathrm{RH}$.

Two, $25 \mathrm{~mm}$ long stainless-steel screws were driven into each specimen $15 \mathrm{~mm}$ from one end to serve as electrodes for moisture content determination. The upper $13 \mathrm{~mm}$ depth of each hole was drilled to a larger diameter and filled with neoprene rubber sealant so that moisture measurements would be taken from the interior of the specimen.

A specimen holder was constructed to allow leaf litter to be trapped against a test specimen (Figure 1). The configuration approximately represents a moisture-trapping design in which the end of a deck board rests on doubled rim joists and butts against a fascia board. The specimen holders were constructed from $38 \mathrm{~mm}$ thick western redcedar lumber. Four drain holes were drilled through the bottom of the specimen holder. The specimens were placed flat in the bottom of the specimen holder, with $10 \mathrm{~mm}$ gap on all 4 sides of the test specimen. The designated type of leaf litter (if any) was then lightly packed into the gap around all 4 sides of the specimens until it was slightly below the upper surface of the specimen. Both the aged and young leaf litter were sterilized by autoclave prior to use to eliminate existing fungal growth. The specimens/holders were placed onto an above-ground rack at a 
test site west of Madison, Wisconsin, USA in June of 2012. Shade cloth (50\% shading) was stretched over the rack to simulate the shading that might occur in areas of leaf litter deposition.

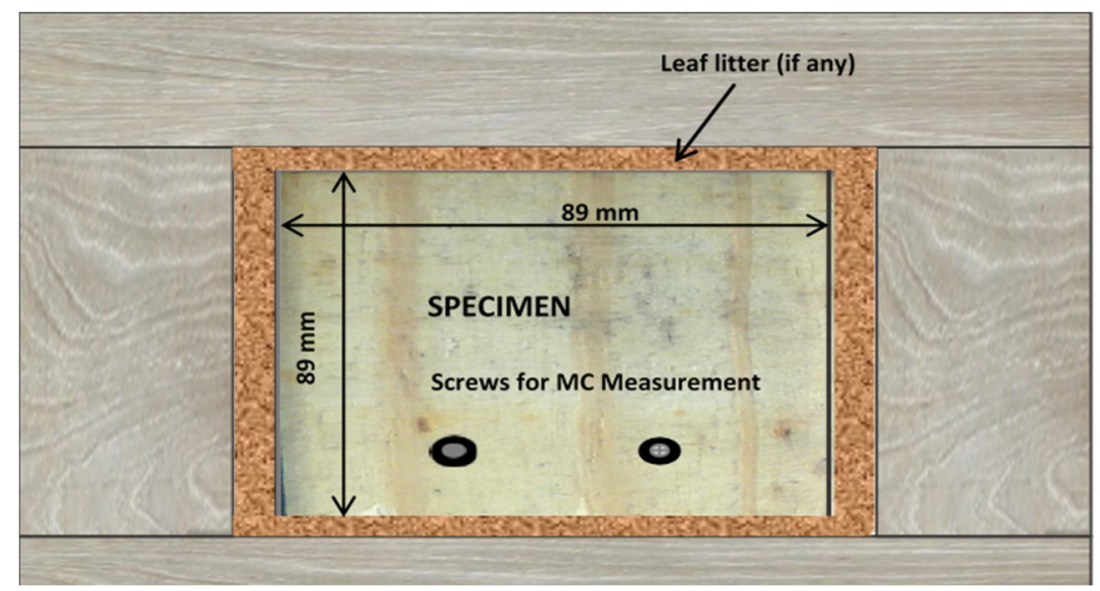

Figure 1. Physical configuration of specimen holder used in this study. The wood block was surrounded by either aged or leaf litter and allowed to weather. Black holes near the bottom were used to obtain moisture content at each observation. The assembly shown represents one replicate.

\subsection{Specimen Evaluations}

Moisture Content: Specimen moisture content was evaluated on an approximate weekly basis using a General Electric Protimeter Timbermaster (Amphenol, St. Mary, PA, USA), resistance type moisture meter. The internal calibration recommended for southern pine was used in this study. Readings were taken by contacting the meter pins with the stainless-steel screws that had been inserted into each specimen. Although the accuracy of resistance type moisture meters declines above the fiber saturation point, recent research has shown that resistance moisture meters can provide useful information on moisture contents above the fiber saturation point when screws are used as the electrodes [2]. Readings were adjusted for wood temperature as described in Lebow and Lebow [2]. Moisture measurements were not conducted during freezing temperatures as initial attempts indicated that readings taken on frozen wood underestimated moisture contents of specimens above the fiber saturation point.

Visual Decay Evaluations: After 4, 13, 24, and 41 months of exposure, the specimens were removed from the holders, brushed free of leaf litter (if applicable), and visually examined for evidence of fungal decay. They were assigned a condition rating patterned after that described in the American Wood Protection Association (AWPA) Standard E18 [1,41] $(\mathrm{O}=$ failed, $10=$ sound, with ordinal ratings 9-4 based on percent removal of wood cross section due to decay). The specimens were then returned to the holders and re-packed with the original leaf litter plus any additional litter needed to bring up to the original depth (if applicable). A visual example of an untreated pine block at the end of the test is presented in Figure 2.

Comparisons of the visual ratings for the different treatment groups were based on a cumulative logit model estimated with SAS ${ }^{\circledR}$ V9.4 (SAS Institute Inc., Cary, NC, USA) procedure GLIMMIX with main effects for treatment groups and exposure time and a random effect for specimens to capture dependencies for repeat measurements over time. 


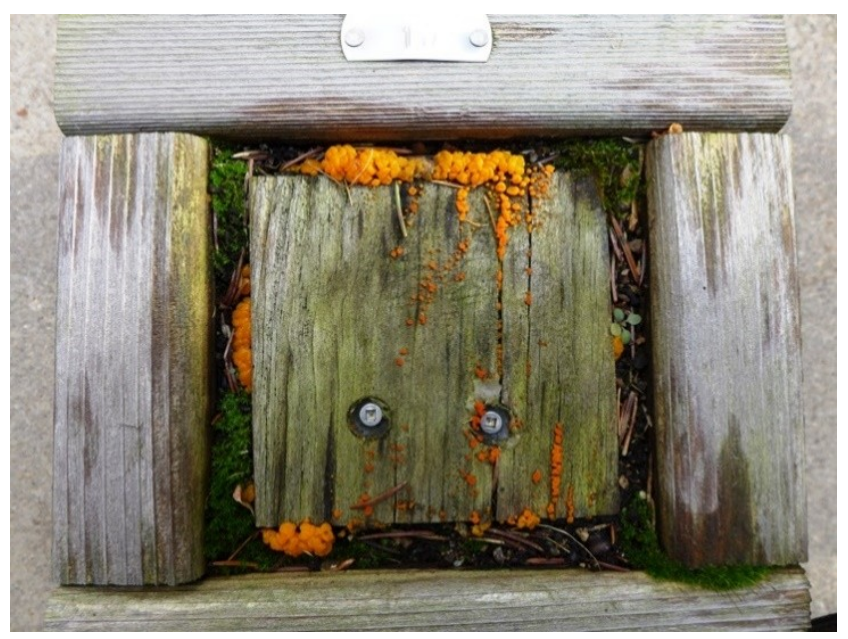

Figure 2. Visual example of untreated pine block at the end of the test. Note moss growth indicative of high moisture content and surface growth of saprophytic fungi on the surface of the block, presumably Dacrymyces spp. (likely capitatus).

\subsection{Amplicon-Based Sequence Analysis}

Amplicon-based sequencing analysis of the microbial community associated with both specimens and leaf litter was also conducted at two time points. After 25 and 41 months of exposure, selected samples of leaf litter and of wood from the specimens were collected for amplicon-based sequencing analysis. Amplicon-based sequencing was based on 4 replicates of each treatment group. Wood samples were obtained by drilling into the bottom of specimens $13 \mathrm{~mm}$ from the end grain and $13 \mathrm{~mm}$ from an edge of the wood. For simplification and cost effectiveness, only leaf litter and wood samples from untreated wood were analyzed. Samples of unexposed young and aged litter controls were included at both time points. Leaf litter samples were frozen at $-30^{\circ} \mathrm{C}$ for approximately 1 month before processing. Samples were mixed by hand in the plastic sample bag, $0.25 \mathrm{~g}$ was weighed out and DNA extracted using the MoBio Power Soil DNA Isolation Kit (Qiagen, Germantown, MD, USA). The $100 \mu \mathrm{L}$ DNA solutions were then cleaned using the MoBio Powerclean Pro DNA Clean-up Kit (Qiagen, Germantown, MD, USA), then quantified by Biotek spectrophotometer (Biotek, Winooski, VT, USA) and diluted to $10 \mathrm{ng} / \mu \mathrm{L}$ in $10 \mathrm{mM}$ Tris $1 \mathrm{mM}$ EDTA (TE, $\mathrm{pH} 8$ ).

Sawdust was frozen at $-30{ }^{\circ} \mathrm{C}$ for approximately 1 month before processing. Samples were mixed by hand and $0.1 \mathrm{~g}$ was added to $800 \mu \mathrm{L} 2 \%$ CTAB buffer with $0.1 \%$ beta-mercapto-ethanol and ground for $30 \mathrm{~s}$ with a hand drill and plastic pestle. Samples were then incubated $1 \mathrm{~h}$ at $65{ }^{\circ} \mathrm{C}$ and centrifuged $15,000 \times g$ for $3 \mathrm{~min}$. Supernatants were transferred to spin columns from the Promega Wizard SV Genomic DNA Purification Kit (Promega, Madison, WI, USA) and manufacturer instructions for purification were followed. Samples were re-suspended in $100 \mu \mathrm{L}$ water with RNAse inhibitor as recommended then diluted to $2 \mathrm{ng} / \mu \mathrm{L}$ in TE $\mathrm{pH} 8$.

Twenty-five nanograms of leaf litter DNA and 5 ng wood DNA samples were amplified in triplicate by PCR using ITS1F (CTTGGTCATTTAGAGGAAGTAA) and ITS2 (GCTGCGTTCTTCATCGATGC) primers with Illumina adapters for the MiSeq platform (Illumina, San Diego, CA, USA) and 22 unique identifiers on the reverse primers. The amplified region of interest is the internally transcribed spacer region 2 (ITS2) as described in De Gannes et al. [42]. Phusion Hot Start Flex DNA Polymerase (New England Biolabs, Ipswich, MA, USA) in HF buffer was used for PCR's with the following program: 4 min at $94{ }^{\circ} \mathrm{C}$, followed by 30 cycles of $30 \mathrm{~s}$ at $94{ }^{\circ} \mathrm{C}, 60 \mathrm{~s}$ at $50{ }^{\circ} \mathrm{C}$, and $90 \mathrm{~s}$ at $72{ }^{\circ} \mathrm{C}$ and a final extension of $10 \mathrm{~min}$ at $72{ }^{\circ} \mathrm{C}$. A $400 \mathrm{bp}$ product was confirmed on $2 \%$ Agarose gel electrophoresis. Each set of replicates was combined and cleaned up with Agencort AMPure XP beads (Beckman Coulter, Indianapolis, IN, USA) following manufacturer instructions. Cleaned samples were quantified using the Quant it DNA Assay Kit (high sensitivity, Invitrogen, ThermoFisher Scientific, Waltham, MA, 
USA) using the microplate procedure and the Biotek Synergy H1 multimodal plate reader (Winooski, VT, USA). Samples were normalized to $10 \mathrm{nM}$ and combined, then submitted to the University of Wisconsin-Madison Biotechnology Center-DNA Sequencing Facility for Illumina MiSeq sequencing.

Amplicon-based sequencing data were processed using the AMPtk v1.3 pipeline. AMPtk is a series of scripts to process NGS amplicon data using USEARCH and VSEARCH, it can also be used to process any NGS amplicon data and includes databases setup for analysis of fungal ITS, fungal LSU, bacterial 16S, and insect COI amplicons. It is compatible with Ion Torrent, MiSeq, and 454 data [43]. For this analysis, overlapping $2 \times 250$ bp Illumina MiSeq reads were merged using USEARCH9 [44], forward and reverse primers were removed from the merged reads, and the reads were trimmed or padded with N's to a set length of $250 \mathrm{bp}$. Operational taxonomic units (OTUs) were generated for each sample, which is used to describe taxonomically distinct groups of fungi [45]. Processed reads were quality trimmed based on accumulation of expected errors less than 1.0 [46] and clustered using the UPARSE algorithm using default parameters (singletons removed, 97\% OTU radius). An OTU table was generated by mapping the original reads to the OTUs using VSEARCH 1.9.1 [47] and the OTU table was subsequently filtered to eliminate "index-bleed" at $0.5 \%$. Taxonomy was assigned using a combination of UTAX and global alignment (USEARCH [44] to the UNITE database [48]) and non-fungal OTUs were removed prior to downstream data processing.

\subsection{Community Analysis and Species Richness Analysis}

PCORD 7.29 (MjM Software Design, Gleneden Beach, OR, USA) [49] was used to perform community analysis to provide more quantitative information on specific relationships within the data set. Lack of fit was evaluated based on PCORD's stress and instability measurements. Output OTU tables from the previous section were imported and used to address the following questions:

1. Does time of exposure to leaf litter impact fungal colonists in the wood ( $25 \mathrm{vs} .41$ months)? Comparisons performed on wood only—removed all leaf litter from the dataset. Fungal matrix had OTUs occurring less than 10 times removed (total of 677 OTUs analyzed). Fungal matrix was relativized by sample unit to standardize sampling depth. Groupings were made of wood from each sample period ( 25 months, 41 months) exposed to each litter type (no litter, aged, and young) resulting in six factorial treatment groups of interest. Nonmetric multidimensional scaling (NMDS) ordinations and multi-response permutation procedures (MRPP) were performed using the Sorensen distance measure for both. Group comparisons of interest for this question included 1v4, 2v5, 3v6. Additionally, groups 1-3 (25 months) and 4-6 (41 months) (Table 2) were combined for an additional MRPP analysis to look at the effect of year on wood fungal communities.

2. How well does community structure match from litter to wood? Comparisons performed on all samples, both leaf litter and wood. Fungal matrix had OTUs occurring less than 10 times removed (total of 2223 OTUs analyzed). Fungal matrix was relativized by sample unit to standardize sampling depth. Groupings were made of each leaf litter type (aged, young) and wood exposure type (aged litter, young litter) were compared between sampling periods ( 25 months, 41 months) for a total of eight exposure scenarios to compare similarity between the leaf-litter to the wood to which it was exposed. Non-metric multidimensional scaling (NMDS) and MRPP were performed using Sorensen distance measure for both. Group comparisons of interest for this question included 1v5, 2v6, 3v7, 4v8 .

3. Were there any differences between aged and non-aged litter? These analyses were run on the whole dataset.

In addition to the aforementioned analyses, indicator species analyses (ISAs) [50] were used to detect, and describe the significance of, fungal taxa indicative of a priori treatments [51]. Due to multiple group-comparisons, only highly significant taxa were included. Additional tests of species richness were also performed in PC-ORD to determine the contributions of organic detritus to species richness when placed in contact with wood. Diversity measures were calculated using the following formulae:

$$
S=\text { Richness }=\text { total count of non-zero elements in a row }
$$




$$
\begin{gathered}
E=\text { Evenness }=H / \ln (S), \\
H=\text { Diversity }=\operatorname{sum}\left(P i^{*} \ln (P i)\right),
\end{gathered}
$$

$D=$ Simpson's diversity index $=1-\operatorname{sum}\left(P i^{*} \mathrm{Pi}\right)$, where $\mathrm{Pi}=$ importance probability in element I (element I relativized by row total).

\subsection{Functional Guilds Analysis}

To provide additional contextual information on the fungal species from this study, OTUs from ampTk were further processed using Funguild [52], an online tool for characterizing fungal species within a community based on their ecological roles. Funguild builds on taxonomy data in the output OTU table to include ecological function for each identified fungal species and classifies them based on biological function (saprophyte, parasite, endophyte, etc.), wood saprobes are also characterized in Funguild and decay type is typically indicated as brown, white, or soft rot fungi. The goal of the guilds characterization was to determine if different groups of fungi predominate when leaf litter sources were varied or absent and to determine if the presence of absence of leaf litter had any impacts on the guild composition which could in turn affect rates of wood decay.

\section{Results}

\subsection{Specimen Moisture Content}

As expected, contact with leaf litter was associated with higher moisture contents in all the untreated and wood specimen and this effect was observed with both the aged and young leaf litter for the untreated specimens (Figure 3). Within 6 months of exposure, untreated specimens in contact with leaf litter had moisture contents consistently above $30 \%$, and moisture contents were above $40 \%$ for the vast majority of the exposure period. Even the specimens exposed without leaf litter often had moisture contents above $30 \%$ by the second year of exposure. Average moisture contents were slightly lower in the treated specimens, but those in contact with aged leaf litter typically had moisture contents above $30 \%$ and often had moisture contents above $40 \%$.

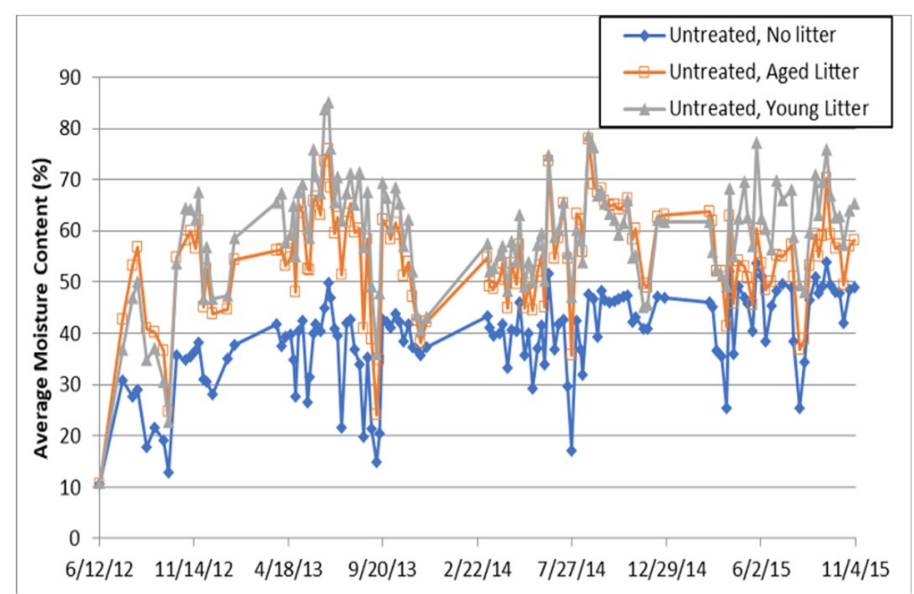

Figure 3. Average moisture content for unexposed wood blocks compared to wood exposed to aged and young leaf litter $(n=5)$. Note higher swings in moisture content when leaf litter is present and slightly higher moisture content (MC) in aged vs. young litter. Error bars omitted for readability. Average standard errors were $2.4 \%, 4.20 \%$, and 3.63\% for no leaf litter, aged leaf litter, and young leaf litter, respectively. 


\subsection{Visual Decay Evaluations}

The specimens placed in contact with aged leaf litter exhibited more evidence of fungal decay than did specimens not placed in contact with leaf litter $(p=0.0002)$, as did specimens placed in contact with young leaf litter $(p=0.0005$; Figure 4$)$. After 41 months of exposure, one of the untreated specimens exposed to aged leaf litter was so decayed that it crumbled upon removal from the specimen holder and was rated as a " 0 " on the adopted AWPA rating scale. This specimen also had a carpenter ant infestation. A second untreated specimen exposed to aged leaf litter was sufficiently decayed to rate a " 6 " on the AWPA rating scale. Although the aged leaf litter specimen ratings were not statistically different than those for the young leaf litter across time $(p=0.3100)$, they were statistically different at 41 months $(p=0.0003)$. One of the treated specimens exposed to the aged litter (not coincidentally a specimen with low preservative retention) also had clear evidence of decay along one edge. Decay was less obvious in specimens in contact with the young leaf litter, but two untreated specimens did have some decay. Only one untreated specimen not in contact with leaf litter showed slight evidence of decay, although a second specimen was considered to have "possible" early stages of decay.

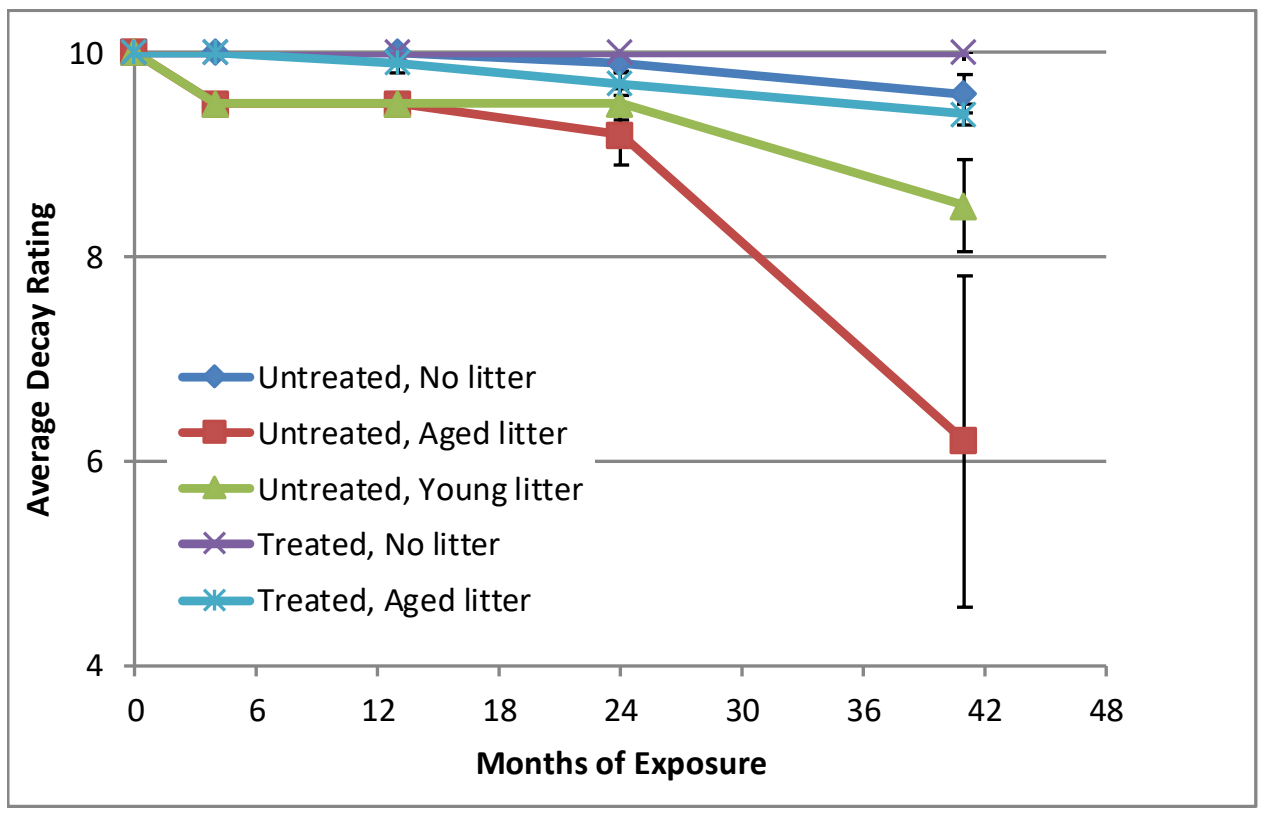

Figure 4. Average decay rating $(n=5)$ of above-ground wood samples in different exposure scenarios. For comparative purposes, treated wood both with and without litter are included in this figure but not discussed in the manuscript. Note faster rate of decline in decay rating of untreated wood in contact with aged litter compared to both young litter and litter free exposure scenarios.

\subsection{Amplicon-Based Sequencing Analysis}

A total of 3352 fungal OTUs were recovered from the metagenomic analysis. Taxonomically, 1948 of the recovered OTUs were Ascomycetes, 537 were Basidiomycetes, 162 Glomeromycetes, with fewer representatives of the Mucoromycetes or other relevant species. In addition, 361 Agaricomycete OTUs were recovered, these include the mushroom forming fungi that comprise most of the commonly known decay fungi. Fifty OTUs classified as belonging to the order Polyporales were recovered. A complete OTU table with annotated taxonomic designations for all samplings is available as Supplemental Table S1 on the MDPI website. The OTU table generated using AMPtk was imported for further community analysis using PC-ORD and Funguild [40]. Amplicon-based sequencing data has been archived at the National Center for Bitoechnology Information (NCBI) sequence read archive (SRA) under Bioproject\# PRJNA612060. 


\subsection{Community Analysis and Species Richness Analysis}

The results of the community analysis showed differences between treatments based on the fungal species composition in wood both with and without leaf litter and across sampling intervals. Combined for both years, aged leaf litter had a distinctly different fungal community than young leaf litter (MRPP $p=0.0001 \mathrm{~A}=0.123$ ). Significant differences were noted between aged and young litter and wood exposed to either young or aged litter. The results from the community analysis are summarized in Table 3 and contain references to proceeding Non-metric Multi-dimensional Scaling (NMDS) ordinations as well as contain lists of indicator species associated with comparisons of interest.

Table 3. Community analysis results grouped with Indicator species analysis results. Grouping and treatment indicate exposure scenarios of interest while Figure relevance references resulting Non-Metric Multidimensional Scaling (NMDS) ordinations produced from the data. Lastly, indicator species derived from those exposure scenarios are listed by treatment group. ${ }^{\mathrm{a}} \mathrm{IV}=$ Maximum indicator value, ${ }^{\mathrm{b}} p$-value $=$ significance level; $p<0.01$ indicates highly significant indicator taxa for respective treatments.

\begin{tabular}{|c|c|c|c|c|c|c|}
\hline Grouping & Treatment & $\begin{array}{c}\text { Figure } \\
\text { Relevance }\end{array}$ & Taxon & $\begin{array}{c}\text { Observed } \\
\text { Indicator } \\
\text { Value (IV) }^{a}\end{array}$ & $p$-Value ${ }^{\mathrm{b}}$ & OTU \# \\
\hline \multirow{6}{*}{$\begin{array}{c}\text { Litter } 25 \text { vs. } 41 \\
\text { (Age Combined) }\end{array}$} & Litter 41 & \multirow{6}{*}{ Figure $5 \mathrm{C}$} & Sistotremastrum guttuliferum & 89 & 0.0001 & OTU4 \\
\hline & Litter 41 & & Peniophorella pubera & 86 & 0.0019 & OTU17 \\
\hline & Litter 41 & & Peniophorella praetermissa & 100 & 0.0001 & OTU20 \\
\hline & Litter 41 & & Arrhenia sp. & 90 & 0.0001 & OTU34 \\
\hline & Litter 41 & & Rhodonia placenta & 60 & 0.0095 & OTU45 \\
\hline & Litter 41 & & Sistotremastrum sp. & 100 & 0.0001 & OTU2710 \\
\hline Aged vs. Young & Litter Aged & \multirow{3}{*}{ Figure 5C,D } & Ganodermataceae sp. & 88 & 0.0011 & OTU199 \\
\hline Litter (Years & Litter Aged & & Coprinellus sp. & 88 & 0.0017 & OTU902 \\
\hline Combined) & Litter Aged & & Dacrymyces capitatus & 87 & 0.0081 & OTU23 \\
\hline \multirow{6}{*}{$\begin{array}{l}\text { Aged vs. Young } \\
\text { Litter (Years } \\
\text { Separate) }\end{array}$} & Litter Aged 41 & \multirow{6}{*}{ Figure $5 \mathrm{C}, \mathrm{D}$} & Peniophora sp. & 68 & 0.0096 & OTU578 \\
\hline & Litter Aged 25 & & Polyporus sp. & 79 & 0.0072 & OTU599 \\
\hline & Litter Aged 25 & & Hebeloma sp. & 72 & 0.0025 & OTU724 \\
\hline & Litter Aged 25 & & Hyphodermella sp. & 83 & 0.0096 & OTU815 \\
\hline & Litter Aged 25 & & Coprinopsis sp. & 77 & 0.0026 & OTU929 \\
\hline & Litter Aged 25 & & Lepista sp. & 97 & 0.0026 & OTU1081 \\
\hline \multirow{5}{*}{$\begin{array}{l}\text { Wood } 25 \text { vs. } 41 \\
\text { (Age Combined) }\end{array}$} & Wood 41 & \multirow{5}{*}{ Figure $5 \mathrm{~B}, \mathrm{C}$} & Peniophorella praetermissa & 98 & 0.0001 & OTU20 \\
\hline & Wood 41 & & Subulicystidium brachysporum & 93 & 0.0001 & OTU14 \\
\hline & Wood 41 & & Arrhenia sp. & 73 & 0.0003 & OTU34 \\
\hline & Wood 41 & & Rhodonia placenta & 64 & 0.0014 & OTU45 \\
\hline & Wood 25 & & Sistotrema sp. & 75 & 0.0012 & OTU43 \\
\hline \multirow{3}{*}{$\begin{array}{c}\text { Wood Samples } \\
\text { (Litter Type } \\
\text { Separate) }\end{array}$} & Wood Aged Litter & \multirow{3}{*}{ Figure $5 \mathrm{~A}, \mathrm{C}$} & Peniophorella pubera & 97 & 0.0002 & OTU17 \\
\hline & Wood Aged Litter & & Dacrymyces capitatus & 72 & 0.0014 & OTU89 \\
\hline & Wood No Litter & & Dacrymyces sp. & 84 & 0.0031 & OTU5 \\
\hline \multirow{3}{*}{$\begin{array}{l}\text { Wood Samples } \\
\text { (Litter and Year } \\
\text { Separate) }\end{array}$} & Wood No Litter 25 & \multirow{3}{*}{ Figure $5 \mathrm{~A}, \mathrm{C}$} & Sistotrema sp. & 90 & 0.0007 & OTU43 \\
\hline & Wood Young Litter 41 & & Sistotremastrum sp. & 63 & 0.0051 & OTU2710 \\
\hline & Wood Young Litter 41 & & Arrhenia sp. & 95 & 0.0036 & OTU34 \\
\hline \multirow{20}{*}{$\begin{array}{l}\text { All Leaf and } \\
\text { Wood } \\
\text { Treatments } \\
\text { Separate }\end{array}$} & Litter Aged 25 & \multirow{20}{*}{ Figure $5 \mathrm{C}$} & Hebeloma sp. & 60 & 0.0066 & OTU724 \\
\hline & Litter Aged 25 & & Polyporus sp. & 92 & 0.0052 & OTU599 \\
\hline & Litter Aged 25 & & Hyphodontia sp. & 66 & 0.0053 & OTU650 \\
\hline & Litter Aged 25 & & Hyphodermella sp. & 91 & 0.0015 & OTU815 \\
\hline & Litter Aged 25 & & Coprinopsis sp. & 62 & 0.0065 & OTU929 \\
\hline & Litter Aged 25 & & Lycoperdon sp. & 70 & 0.0067 & OTU935 \\
\hline & Litter Aged 25 & & Coprinellus sp. & 96 & 0.0009 & OTU902 \\
\hline & Litter Aged 25 & & Coprinellus sp. & 83 & 0.0012 & OTU1160 \\
\hline & Litter Aged 25 & & Ceriporia sp. & 75 & 0.0044 & OTU997 \\
\hline & Litter Aged 25 & & Parmastomyces sp. & 75 & 0.0048 & OTU1105 \\
\hline & Litter Aged 25 & & Lepista sp. & 100 & 0.0002 & OTU1081 \\
\hline & Litter Aged 25 & & Pluteus sp. & 70 & 0.0075 & OTU1582 \\
\hline & Litter Aged 25 & & Crepidotus sp. & 75 & 0.0067 & OTU1612 \\
\hline & Litter Aged 41 & & Cylindrobasidium sp. & 75 & 0.0040 & OTU1573 \\
\hline & Litter Aged 41 & & Phlebiella sp. & 75 & 0.0040 & OTU1642 \\
\hline & Litter Aged 41 & & Trichaptum sp. & 75 & 0.0040 & OTU1794 \\
\hline & Litter Aged 41 & & Stereum sp. & 75 & 0.0040 & OTU1520 \\
\hline & Wood Aged Litter 25 & & Dacrymyces sp. & 60 & 0.0081 & OTU3403 \\
\hline & Wood No Litter 25 & & Sistotrema sp. & 84 & 0.0004 & OTU43 \\
\hline & Wood Young Litter 41 & & Sistotremastrum sp. & 89 & 0.0035 & OTU2710 \\
\hline
\end{tabular}



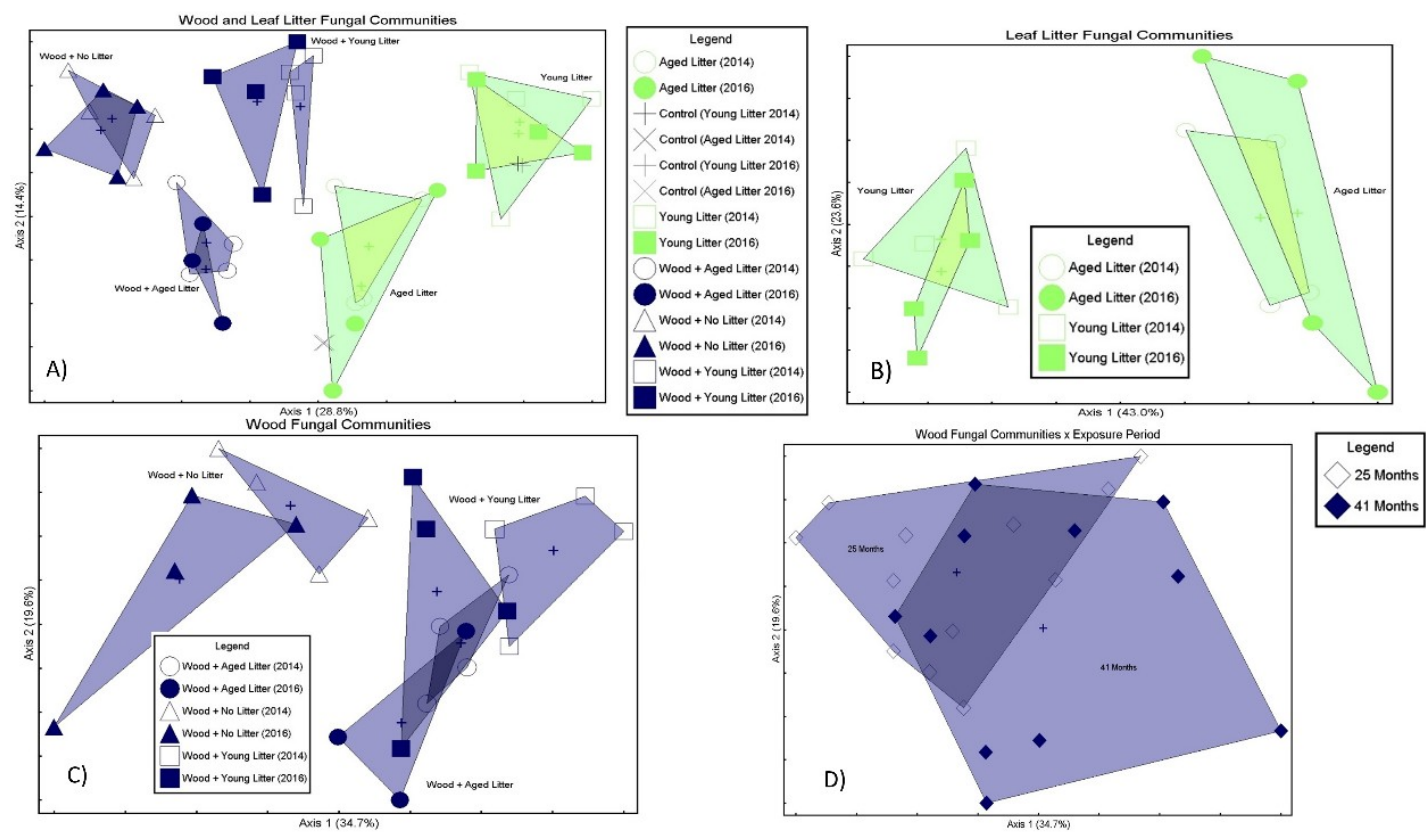

Figure 5. NMDS ordinations depicting: (A) Similarity between wood fungal communities exposed to aged (A), young $(\mathrm{Y})$, or no leaf litter $(\mathrm{N}) ;(B)$ similarities between all treatment groups: unexposed controls (lf14-lf16HM (young) and lf-16SB (aged) compared to exposed leaves leaf14-16Y (young) and leaf14-16A (aged) and finally wood exposed to either young (Y) or aged (A), as well as no litter (N). (C) All samples grouped, overall similarity between fungal communities at the two exposure periods 2014 (25 months) and 2016 (41 months), showing similarities in the fungal communities. (D) NMDS of fungal communities in litter only showing differences in young $(\mathrm{Y})$ and aged $(\mathrm{A})$ litter that persisted over the two sampling times.

To observe the effects of leaf litter on fungal colonists over time ( $25 \mathrm{vs.} 41$ months), multi-response permutation procedures (MRPP) were performed on wood samples only and compared wood from 25 months ( 25 mos.) exposed to aged, young, and no leaf litter to wood from 41 months ( 41 months) subject to similar exposure. MRPP was deemed to be the more suitable option for analysis in this case due to uneven sample numbers, which are not ideal for a more robust analysis, such as permutational multivariate analysis of variance (PERMANOVA). The results (Figure 5A) indicate that wood with no litter (Wood14N and Wood16N) were more similar in species composition than those exposed to either aged (A) or young (Y) litter. NMDS axis 1 accounted for $34.7 \%$ of the variation, NMDS axis 2 accounts for $19.6 \%$ of the variation, and axis 3 (not shown) accounted for $13.4 \%$ of the variation (Stress $=11.998$, Instability $=0.0000$, and $p=0.004$ ).

In order to test overall similarity in community structure from litter to wood, comparisons were made of all samples, both litter and wood and grouped as such: (A) aged leaves 25 months, (B) young leaves 24 months, (C) aged leaves from 41 months, (D) young leaves from 41 months, (E) wood from 24 months with aged litter, (F) wood from 24 months with young litter, $(G)$ wood from 41 months with aged litter, and $(\mathrm{H})$ wood from 41 months with young litter. NMDS and MRPP were performed using Sorenson distance measure and grouped comparisons were made comparing A-E, B-F, C-G, D-H to evaluate the similarity between: (A-E) aged leaves versus wood in 25 months (Not different, $p=0.094$, $\mathrm{A}=0.06)$, (B-F) young leaves versus wood in 25 months (Different, $p=0.004, \mathrm{~A}=0.102),(C-\mathrm{G})$ aged leaves versus wood in 41 months (Not different, $p=0.187, \mathrm{~A}=0.033$ ), and $(\mathrm{D}-\mathrm{H})$ young leaves versus wood in 41 months (Different, $p=0.011, \mathrm{~A}=0.115$ ). The resulting NMDS ordination is presented in Figure 5B. Young and aged leaf litter controls (14CY, 16CY and 14CA, 16CA) at the two time points remain nearly identical in community structure, indicating that there was similar sequencing coverage between time points. The communities' group by leaf type and leaf samples (right side of figure) separate from wood samples (left side of figure). Young leaf samples were significantly different from 
their paired wood at both time points, which could be an indication of early leaf colonizers that may not be able to establish in wood. Other pairings were not significantly different, indicating there may be some carry over directly from aged litter to wood.

Comparing only wood fungal communities without regard to litter treatment groups showed little community differences between wood samples in 25 months and 41 months (MRPP; $p=0.039$; $A=0.017$ ). Based on these results, it is suggested that fungal species composition was mostly similar after 24 and 41 months of above-ground exposure when looking at the wood only (Figure 5C). It should be noted that there were far fewer OTUs detected in wood vs. leaf litter, so this likely has a large influence on this data set. Although the $p$-value was significant, the low A-value indicative of within-group heterogeneity being expected by chance led to our conservative assessment of wood fungal communities.

With wood removed from the dataset (looking at litter only), there are still clear differences between young and aged leaf litter (MRPP $p=0.009, \mathrm{~A}=0.126$ ) regarding fungal species composition (Figure 5D). However, over time, litter species composition stayed relatively similar between 25 months and 41 months for both young (MRPP $p=0.677 ; \mathrm{A}=-0.026)$ and aged (MRPP $p=0.651 ;-0.031$ ) leaf litter.

The results of the indicator species analysis (ISA) are presented previously in Table 3. Indicator species are compiled for several comparisons of interest made during the earlier community analysis. Indicator values were only deemed relevant below the $p=0.01$ level and a calculated indicator score of $60 \%$ or higher $(p<0.01 ; \mathrm{IV} \geq 60 \%)$. As presented in the table, each question required a unique ISA to elucidate ecologically relevant indicator taxa for the comparisons of interest. In each category, the maximum indicator value is an indicator of how often each species occurs in the highlighted condition.

As a final metric of the fungal community, species richness was calculated for each exposure scenario and the results of the richness analysis are shown in Table 4 . No significant differences were noted between evenness, or 2 independent measures of diversity. Some differences were noted in species richness with highest species richness observed in aged leaf litter and lowest species richness observed in wood in contact with aged litter, but this was not significantly different from wood not exposed to leaf litter. Moving the analysis from leaf litter into solid wood presents a significant bottleneck as fungal colonization is limited by space and available moisture.

Table 4. Results of richness analysis. Statistical significance of each richness variable is included in the table, samples with same letter are not significantly different, while those designated with different letters were deemed significant $(p=0.00001)$.

\begin{tabular}{cccccccc}
\hline Treatment & $\begin{array}{c}\text { Time } \\
\text { (mos) }\end{array}$ & N & \multicolumn{2}{c}{$\begin{array}{c}\text { S }= \\
\text { Richness }\end{array}$} & $\begin{array}{c}\text { E }= \\
\text { Evenness }\end{array}$ & $\begin{array}{c}\text { H }= \\
\text { Diversity }\end{array}$ & $\begin{array}{c}\text { D Simpson's } \\
\text { Diversity }\end{array}$ \\
\hline Young Control Leaf Litter & NA & 2 & 365.5 & BC & $0.415 \mathrm{~A}$ & $2.450 \mathrm{~A}$ & $0.8381 \mathrm{~A}$ \\
Aged Control Leaf Litter & NA & 2 & 385.5 & $\mathrm{BC}$ & $0.202 \mathrm{~A}$ & $1.198 \mathrm{~A}$ & $0.5007 \mathrm{~A}$ \\
Young Litter & 25 & 4 & 367.0 & $\mathrm{BC}$ & $0.406 \mathrm{~A}$ & $2.398 \mathrm{~A}$ & $0.8032 \mathrm{~A}$ \\
Aged Litter & 25 & 4 & 533.8 & $\mathrm{AB}$ & $0.423 \mathrm{~A}$ & $2.665 \mathrm{~A}$ & $0.7350 \mathrm{~A}$ \\
Young Litter & 41 & 4 & 494.8 & $\mathrm{AB}$ & $0.392 \mathrm{~A}$ & $2.432 \mathrm{~A}$ & $0.8076 \mathrm{~A}$ \\
Aged Litter & 41 & 4 & 719.8 & $\mathrm{~A}$ & $0.374 \mathrm{~A}$ & $2.479 \mathrm{~A}$ & $0.6990 \mathrm{~A}$ \\
Wood No litter & 25 & 4 & 130.0 & $\mathrm{CD}$ & $0.592 \mathrm{~A}$ & $2.875 \mathrm{~A}$ & $0.8967 \mathrm{~A}$ \\
Wood + Young litter & 25 & 4 & 123.5 & $\mathrm{D}$ & $0.457 \mathrm{~A}$ & $2.179 \mathrm{~A}$ & $0.7859 \mathrm{~A}$ \\
Wood + Aged litter & 25 & 4 & 135.0 & $\mathrm{CD}$ & $0.422 \mathrm{~A}$ & $2.069 \mathrm{~A}$ & $0.7524 \mathrm{~A}$ \\
Wood No litter & 41 & 4 & 102.8 & $\mathrm{D}$ & $0.452 \mathrm{~A}$ & $2.102 \mathrm{~A}$ & $0.7292 \mathrm{~A}$ \\
Wood + Young litter & 41 & 4 & 100.0 & $\mathrm{D}$ & $0.564 \mathrm{~A}$ & $2.594 \mathrm{~A}$ & $0.8498 \mathrm{~A}$ \\
Wood + Aged litter & 41 & 3 & 86.7 & $\mathrm{D}$ & $0.529 \mathrm{~A}$ & $2.357 \mathrm{~A}$ & $0.8192 \mathrm{~A}$ \\
\hline
\end{tabular}

\subsection{Guild Descriptions}

Out of a total of 3213 OTUs, 2070 were assigned guild information using the Funguild [52] software. A complete OTU table with annotated guilds data is presented as Table 2. A total of 257 OTUs were classified as animal pathogens, these are not discussed here as they are likely not involved in 
the breakdown of woody biomass. A total of 144 OTUs were classified as dung saprotrophs (DSAP), mostly characterized as having broad host ranges and occurring on soil, grass, dung, or rotten wood. Sixty-four OTUs were classified as ectomycorrhizal fungi (ECTOMY) of which one was also classified as a white rot (Sistotrema brinkmannii). Twelve OTUs were classified as bryophyte parasites (BRYPAR) (various species of Pluteus, Galerina, and Hymenoscyphus). Only 8 OTUs were classified as arbuscular mycorrhizae and were only identified to the order level (Diversisporales, Gigasporales, Archeosporales, and Glomerales), all within class Glomeromycetes. Pie charts indicating the guild composition of each exposure scenario is presented in Figure 6. A general shift was noted as the litter ages, with the guild composition moving from predominately soil saproptrophs to a more balanced composition that included higher percentages of litter saprotrophs, wood saprotrophs, and fungal pathogens.
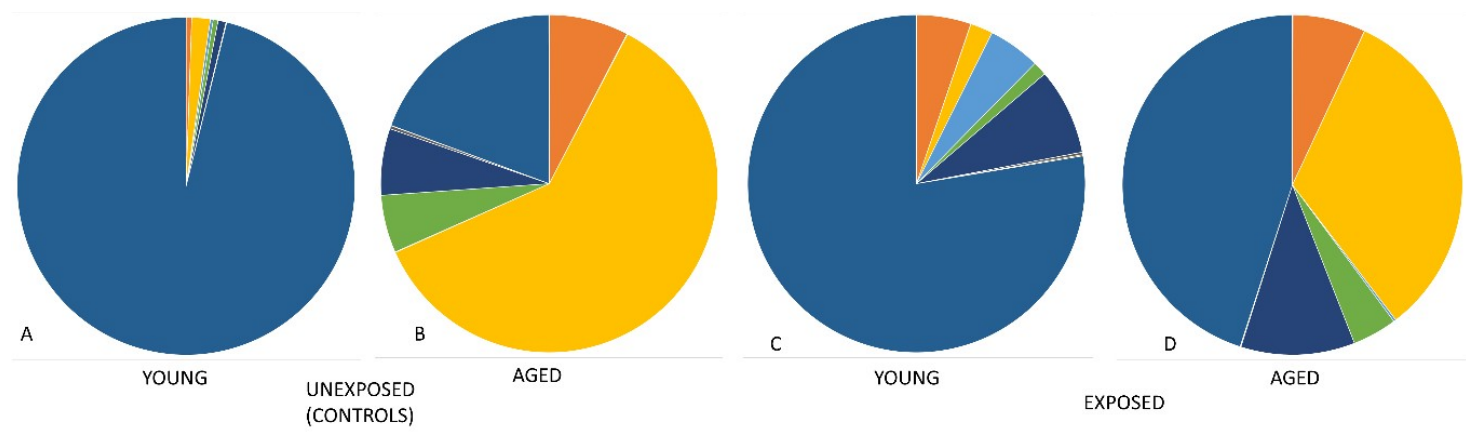

LEAF LITTER GUILD COMPOSITIONS (A-D)
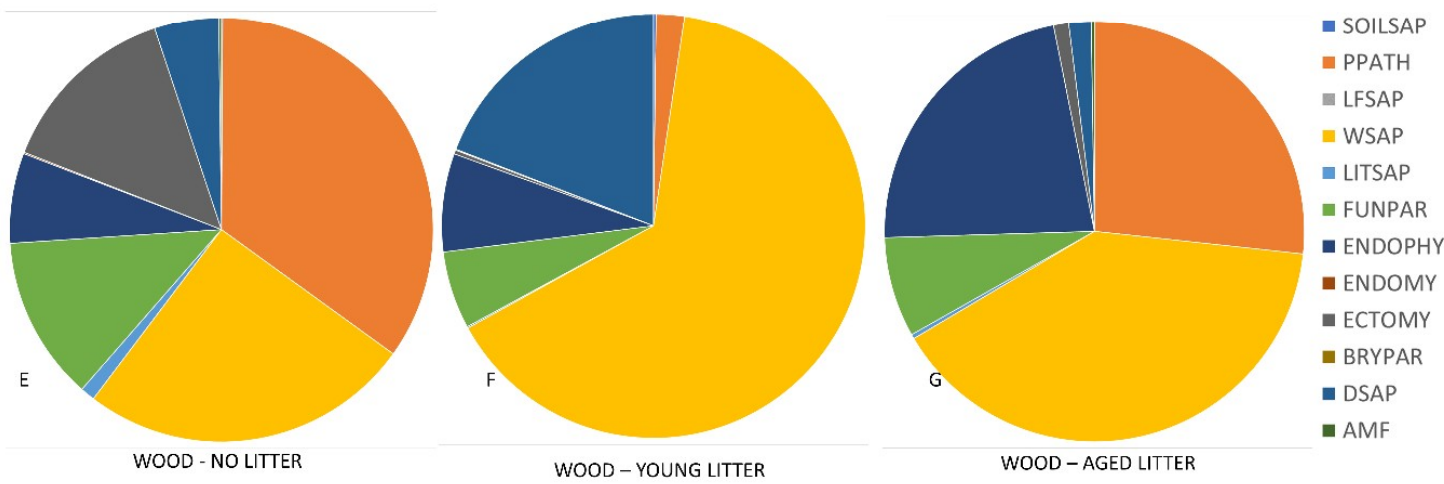

WOOD SAMPLE GUILD COMPOSITIONS (E-G)

Figure 6. Guild composition of fungi under 7 different exposure scenarios. (A) Young litter prior to exposure, (B) aged leaf litter prior to exposure, (C) young litter after exposure, (D) aged litter after exposure, (E) wood with no leaf litter in contact, (F) wood exposed to young leaf litter, and (G) wood exposed to aged leaf litter. Note differences in relative proportion of fungal guilds and increased proportion of wood saprophytes (WSAP) between young and aged litter and wood exposed to both young and aged litter. Functional guild assignments performed using FungGuild [52]. Figure legends to the right are defined in the text.

A total of 353 OTUs were classified as wood saprotrophs (WSAP). These were more prevalent in the litter compared to the wood and between the wood samplings, more were detected in the 41-month sampling. Among the wood saprotrophs, 86 OTUs were described as having traits indicative of soft rot, 63 were described as having traits indicative of brown rot, 54 were described as having traits indicative of white rot, 3 were classified as being either brown or white, but this was due to only being described to the family taxonomic level. The remaining 151 were classified as NULL meaning a functional trait could not be determined. The NULL group was a mixture of microfungi with agaricoid, gasteroid, tremelloid, or phalloid growth morphologies and represent fungi in the database that have not yet been assigned trait information. 
Brown rots were detected in both leaf litter and wood and the predominant species identified was Dacrymyces capitatus. Rhodonia placenta was also detected in wood, but only in the 24-month leaf and wood samples. White rots were much more diverse in both the leaf litter and the adjacent wood, and the most common white rot fungal genera identified were Irpex, Phlebia, Phaeanerochaete, Gleoporus, Ceriporia, Sistronema, Trametes, and Peniophora.

\section{Discussion}

\subsection{Specimen Moisture Content}

It is likely that the lower moisture contents in the treated specimens reflect differences in wood properties rather than an effect of the preservative treatments. Specimens cut from one of the treated parent boards contained heartwood, and these specimens consistently produced relatively low moisture content readings. In general, the moisture readings indicate that the specimens placed in contact with leaf litter had moisture contents conducive for the growth of decay fungi [53-56]. Decay fungi require a moisture content of at least $20 \%$ to sustain any growth, and higher moisture contents (over $29 \%$ ) are required for initial spore germination [14,57]. For optimal growth, brown and white rot decay fungi typically prefer wood in the moisture content range of 40-80\% [58,59]. Soft rot fungi, however, tend to prefer these conditions for colonization and growth [60], which can also severely decay wood under these conditions.

\subsection{Visual Decay Evaluations}

The aged leaf litter contributed to decay development in the untreated specimens and did so to a greater extent than the young leaf litter. There are at least four possible mechanisms for the aged litter promoting decay. One is moisture entrapment and the elevation of specimen moisture content to a range more conducive to fungal growth [14]. Another is that the litter served as the germination site for inoculum that subsequently colonized the wood [61]. A third possibility is that the fungi initially became established in the wood but benefited from nutrient, extractives, or lignified residues that diffused into the wood from the leaf litter [62-64]. A fourth possibility is that there are simply fungi present that can decompose both litter and wood [34]. Moisture content does not appear to be the sole mechanism because the specimens in contact with young leaf litter had similar moisture contents but exhibited less evidence of decay. Some of the specimens not in contact with any leaf litter also maintained relatively high moisture contents.

\subsection{Amplicon-Based Sequencing Analysis}

The results of this study agree with the basic findings of many studies that have focused on the dynamics of fungi in leaf litter [8,11,34,35,62,65-68]. As leaves accumulate, they typically contain a lot of leaf and soil saprophytes, that can readily break down the leafy debris into less complex and more nutritionally devoid substances [69-74]. As the composition of the leaf litter changes to more closely resemble soil, the composition of fungi found in the litter shift and reflect a more specialized consortium of fungi that can readily exploit more nutrient poor resources [35], which is the situation in wood. These fungi are those that are able to exploit the basic structural components (cellulose, hemicelluloses, and lignin) that make up the recalcitrant portions of the leaf litter (petioles, branches, twigs, etc.) as well as any non-durable wood that comes in contact with the leaf litter. Lignin content has been the focus of several studies as a rate limiting factor in decomposition and nutrient cycling, where proportional shifts in more the recalcitrant compounds serves to throttle litter decomposition as a conservation strategy to prevent depletion of soil nutrients $[32,62,64,75,76]$ and would also theoretically select for fungi that are able to break down lignin, i.e., white rot fungi $[11,63]$. The compositional shift that was noted in our study has been reported by several additional studies $[35,77,78]$ and others, where a gradual replacement of ascomycetous fungi (leaf saprobes) with more basidiomycetous (wood saprobe fungi) due to the changing litter composition, also noted in Zhang et al. [35]. This result 
highlights the importance of routine preventative maintenance of wood in above-ground exposures because over time the fungal composition will shift, and the result will be higher inoculum loads of wood decay basidiomycetes present in close contact with the wood surfaces.

\subsection{Community and Richness Analysis}

When comparing litter between samplings (Age Combined, Table 3), a total of six fungal species were found to be significantly associated with the leaf litter after 41 months of test exposure (Sistotremastrum guttuliferum, Peniophorella pubera, Peniopherella praetermissa, Arrhenia spp., Rhodonia (Postia) placenta, and another species of Sistotremastrum only identified to the genus level). Peniophorella praetermissa was identified as a prominent white rot isolated by Clausen and Lindner when looking at performance of shaded pine and maple lap joints, also in Madison, WI [79]. When comparing the aged to young litter (Years Combined), three fungal species were found to be associated with the aged litter (Ganodermataceae sp., Coprinellus sp., and Dacrymyces capitatus). Several species of Dacrymyces are occasional rots on wood including external wood work [80], window framing [81], or spruce shingles [82], but all seem to be overly wet environments similar to this study. Fruiting bodies of fungi resembling Dacrymyces sp. were photographed on samples at the end of this study (Figure 2), so these results were consistent with conditions observed during the test. When data are separated by year (Years Separate), Polyporus spp., Hebeloma spp., Hyphodermella spp., Corinopsis spp., and Lepista spp. were all found to be significantly associated with aged litter after 25 months of field exposure, while Peniophera spp. was found to significantly associated with the aged litter samples after 41 months exposure. When comparing the fungal taxa only in the wood (Age Combined), Sistotrema spp. was found to be significantly associated with wood samples after 25 months exposure while Subulicystidium brachysporum, Arrhenia sp., and Rhodonia placenta were found to be significantly associated with wood samples after 41 months exposure. R. placenta is commonly used in laboratory assays to evaluate decay resistance and has been shown to modify lignin in decayed samples [76], the remainder of these fungi are commonly found on late state coarse wood debris.

It is worth noting the abundance of ectomycorrhizal (ECM) fungi found within each of the above comparisons which indicates ECM fungi may contribute to the overall litter and wood decay fungi processes although they are not always considered as such. ECM fungi were also abundant in previous samplings by Kirker et al. [83] looking at soil fungal communities in soils subjected to long term preservative exposure. Prior studies have also noted the importance of ECM fungi in the overall decay process [78,84-86] as well as potential soil bioremediation tools [87-90].

The overall results of these analyses indicate that aged organic detritus appears more similar to and likely contributes a fair amount to the species composition of the adjacent wood and that young and aged litter develop distinct fungal communities. Young litter likely promotes growth and establishment of more litter decomposing fungi than wood decay fungi.

\subsection{Guild Descriptions}

As noted previously, a general shift in guild composition was noted as the litter aged and was also observed in wood exposed to aged litter. It is suspected that this shift is in response to the changing nutritional value of the substrate which would in turn select for a higher proportion of fungi that can breakdown the remaining woody biomass, which would also agree with the findings of Purahong [34,35,91,92] and Zhang et al. [35] demonstrating shifts in community composition as the substrate is altered. The majority of the OTUs classified as dung saprotrophs were isolated from the leaf litter, but some were detected in wood as well (Preussia pilosella, Sprorormia subticinensis, Sordaria fimicola, Chaetomium globosum). As noted previously in the results, one of the detected fungal OTUs is considered to have both ectomycorrhizal characteristics but is also often characterized as a white rot fungus. S. brinkmannii is considered a weak white rot fungus and is often followed in succession with more late stage wood rot fungi such as Stereum hirsutum or Bjerkandara adusta [93]. Interestingly, S. brinkmannii may be capable of both significant wood decay and for ectomycorrhizal 
associations with both conifers and hardwoods [94,95]. Since there was only one specimen that rotted to the point of failure on our rating scale after 41 months, most of these samples would be considered at early stages of decay. Relatively high diversity of ectomycorrhizal fungi were detected in the leaf litter (both young and aged) and representatives of corticoid (ex. Sistoterma, Tulasnella, and Tomentella), agarocoid (ex. Tricholoma, Hebeloma, Russula, Cortinarius), boletoid (ex. Suillus spp. and Fuscoboletinus spp.), clavaroid (ex. Thelephora spp.), and gasteroid (ex. Scleroderma, Tuber, and Elaphomyces spp.) basidiomycete fungi were detected, as well as numerous microfungi, which were only classified to the family level (Helotiaceae and Ceratobasidaceae). Ectomycorrhizal fungi are typically considered symbionts in the soil environment and not considered active wood decay fungi, however previous studies have shown that they are an integral part of nutrient cycling in forest soils and leaf litter [96-98].

Comparing brown rots to white rots, much less diversity was noted in the brown rot guilds compared to the white rot guilds. This is likely due to the composition of the substrate; the leaf litter was composed of mostly hardwood leaves and would theoretically support growth of white rot fungi over brown rots and the data bear this out to some degree [99-102]. There were noticeable temporal differences in certain fungi, but these should not be attributed to early or late successional histories based on our limited sampling; further studies would be needed to substantiate these in a meaningful way. Soft rot fungi were more prevalent in the leaf litter and sporadic in the wood but did increase in numbers between the 24- and 41-month wood samples. Among the unassigned or NULL trait group, the majority of these OTUs were only found in the leaf litter samples and only a few OTUs (Fusarium, Cladopsorium and Orbilia spp.) were detected in the wood samples. A notable exception was Simocybe sumptuosa, which is a brown spored agaric in the Crepidotaceae family that has been previously isolated from Picea logs in Norway [103]. This species was detected in the 24-month wood samples but not the 41-month wood samples. The diverse pool of wood saprophytes detected in this study give clear indication that the buildup of organic detritus on and adjacent to wood above-ground provides a ready source of fungal inoculum and that many of these fungal species can readily colonize wood given the proper conditions. The wood samples processed in the genomic portion of this study were untreated southern pine and additional studies are on-going to understand this process in wood that is chemically treated.

\section{Conclusions}

The purpose of this study was to demonstrate that leaf litter presents a ready source of fungal inoculum for wood above-ground and can negatively impact the performance of untreated wood. The results of this study highlight several important factors for consideration: The first is that the buildup of organic detritus contributes to the moisture accumulation and subsequent moisture content of adjacent wood. The second is that aged litter in contact with wood in above-ground scenarios contributes to increased wood decay over the 41-month exposure. Additionally, organic detritus contributes to the above-ground decay process by providing a large and diverse assemblage of fungal inoculum including wood decay fungi. Over time, the proportion of wood decay fungi increases as the litter ages and compositionally becomes more similar to soil. If this is applied to an above-ground decking situation, years of accumulation of leaf litter can collect in inaccessible areas and the result is potentially ground contact decay pressure in a very localized area. This can affect not only the surface decking, but also the adjacent sub-structural elements, such as deck joists and ledger boards. Although the fungal community established in the young litter was significantly different from the adjacent wood, there was similarity between the aged litter fungal community and the wood exposed to the litter at both time points. Communities detected in both leaf litter types in 24 months remained in the litter at 41 months indicating that the organisms persist once established. Similarly, those fungi detected in wood at 24 months were similar to those detected at 41 months. The unexposed wood (no litter) was the least similar suggesting that without litter there was less inoculum available in proximity to the wood and inoculum may come from outside sources. A shift in community and guild composition between aged and young litter that persisted through subsequent samplings. While ascomycetes 
predominated the earlier exposures, more basidiomycetes were present in the aged litter. The results of this study raise an important consideration when protecting wood exposed above-ground: If leaf litter is not routinely removed from the wood surface, a more severe decay risk may be present than prescribed in current building code designations. Areas where leaf litter is likely to collect and not accessible to routine maintenance may require wood preservative retentions intended for ground contact scenarios. Future studies will build on this concept and use a similar approach to understand these exposure scenarios at different weathering sites and when leaf litter is exposed to chemically treated wood.

Supplementary Materials: The following are available online at http://www.mdpi.com/2076-2607/8/5/696/s1. Table S1-Operational Taxonomic Units (OTU) table summarizing counts of OTUs by sample. Table S2-OTU table with assigned guild designations summarizing distribution of guild composition by sample.

Author Contributions: S.L.-design of experiment, collection of field data, analysis and interpretation of field data, co-authored manuscript, P.L.-statistical analysis, J.P.-software development and consultation, N.B.-source code, python consultation, A.B.-PCR and metagenomics sample prep, manuscript, J.C.-community analysis of metagenomics data, G.T.K.-data analysis, metagenomics concept, co-authored manuscript. All authors have read and agreed to the published version of the manuscript.

Funding: This research received no external funding.

Acknowledgments: The authors acknowledge the assistance of Steven Halverson of the USDA Forest Products Laboratory for his assistance in preparing the specimens and specimen holders used in this study. The use of trade or firm names in this publication is for reader information and does not imply endorsement by the U.S. Department of Agriculture of any product or service. The Forest Products Laboratory is maintained in cooperation with the University of Wisconsin. This article was written and prepared by U.S. Government employees on official time, and it is therefore in the public domain and not subject to copyright. J.D. Palmer is currently employed by Dupont Industries but was not when this research was conducted. The remaining authors declare that the research was conducted in the absence of any commercial or financial relationships that could be construed as potential conflicts of interest.

Conflicts of Interest: The authors declare that the research was conducted in the absence of any commercial or financial relationships that could be construed as a potential conflict of interest. No funding sources had any role in the design of the study; in the collection, analyses, or interpretation of data; in the writing of the manuscript, or in the decision to publish the results.

\section{References}

1. Association, A.W.P. AWPA 2014 Book of Standards; AWPA: Birmingham, AL, USA, 2014.

2. Lebow, S.T.; Ohno, K.M.; Lebow, P.K.; West, M.H. Efficacy of alternative copper-based preservatives in protecting decking from biodegradation. Maderas. Cienc. Tecnol. 2020. [CrossRef]

3. Lejon, D.P.H.; Chaussod, R.; Ranger, J.; Ranjard, L. Microbial Community Structure and Density Under Different Tree Species in an Acid Forest Soil (Morvan, France). Microb. Ecol. 2005, 50, 614-625. [CrossRef]

4. Tedersoo, L.; Bahram, M.; Põlme, S.; Kõljalg, U.; Yorou, N.S.; Wijesundera, R.; Ruiz, L.V.; Vasco-Palacios, A.M.; Thu, P.Q.; Suija, A. Global diversity and geography of soil fungi. Science 2014, 346, 1256688. [CrossRef]

5. De Bellis, T.; Kernaghan, G.; Widden, P. Plant community influences on soil microfungal assemblages in boreal mixed-wood forests. Mycologia 2007, 99, 356-367. [CrossRef]

6. Edman, M.; Gustafsson, M.; Stenlid, J.; Jonsson, B.G.; Ericson, L. Spore deposition of wood-decaying fungi: Importance of landscape composition. Ecography 2004, 27, 103-111. [CrossRef]

7. Veen, G.; Snoek, B.L.; Bakx-Schotman, T.; Wardle, D.A.; van der Putten, W.H. Relationships between fungal community composition in decomposing leaf litter and home-field advantage effects. Funct. Ecol. 2019, 33, 1524-1535. [CrossRef]

8. Bora, T.; Bezbaruah, B. Accelerated Transformation of Leaf-Litter through Cellulolytic Bacteria and Fungi. Indian J. Agr. Sci. 1992, 62, 678-683.

9. Unterseher, M.; Peršoh, D.; Schnittler, M. Leaf-inhabiting endophytic fungi of European Beech (Fagus sylvatica L.) co-occur in leaf litter but are rare on decaying wood of the same host. Fungal. Divers. 2013, 60, 43-54. [CrossRef]

10. Gora, E.M.; Sayer, E.J.; Turner, B.L.; Tanner, E.V. Decomposition of coarse woody debris in a long-term litter manipulation experiment: A focus on nutrient availability. Funct. Ecol. 2018, 32, 1128-1138. [CrossRef] 
11. Hishinuma, T.; Azuma, J.I.; Osono, T.; Takeda, H. Litter quality control of decomposition of leaves, twigs, and sapwood by the white-rot fungus Trametes versicolor. Eur. J. Soil. Biol. 2017, 80, 1-8. [CrossRef]

12. Carll, C.G.; Highley, T.L. Decay of wood and wood-based products above ground in buildings. J. Test. Eval. 1999, 27, 150-158.

13. Kirker, G.; Winandy, J. Above Ground Deterioration of Wood and Wood-Based Materials. Chem. Stud. Success Field-Test. Evid.-Based Guide 2014, 1158, 113-129.

14. Brischke, C.; Rapp, A.O. Dose-response relationships between wood moisture content, wood temperature and fungal decay determined for 23 European field test sites. Wood Sci. Technol. 2008, 42, 507-518. [CrossRef]

15. Kerekes, J.; Kaspari, M.; Stevenson, B.; Nilsson, R.H.; Hartmann, M.; Amend, A.; Bruns, T.D. Nutrient enrichment increased species richness of leaf litter fungal assemblages in a tropical forest. Mol. Ecol. 2013, 22, 2827-2838. [CrossRef]

16. Sayer, E.J.; Tanner, E.V. Experimental investigation of the importance of litterfall in lowland semi-evergreen tropical forest nutrient cycling. J. Ecol. 2010, 98, 1052-1062. [CrossRef]

17. Krishna, M.; Mohan, M. Litter decomposition in forest ecosystems: A review. Energy Ecol. Environ. 2017, 2, 236-249. [CrossRef]

18. van der Wal, A.; Ottosson, E.; De Boer, W. Neglected role of fungal community composition in explaining variation in wood decay rates. Ecology 2015, 96, 124-133. [CrossRef]

19. Tanesaka, E.; Masuda, H.; Kinugawa, K. Wood degrading ability of basidiomycetes that are wood decomposers, litter decomposers, or mycorrhizal symbionts. Mycologia 1993, 85, 347-354. [CrossRef]

20. Hammel, K. Fungal degradation of lignin. Driven by nature: Plant litter quality and decomposition. Cadisch KE Giller 1997, 33, 45.

21. Schneider, T.; Keiblinger, K.M.; Schmid, E.; Sterflinger-Gleixner, K.; Ellersdorfer, G.; Roschitzki, B.; Richter, A.; Eberl, L.; Zechmeister-Boltenstern, S.; Riedel, K. Who is who in litter decomposition? Metaproteomics reveals major microbial players and their biogeochemical functions. ISME J. 2012, 6, 1749-1762. [CrossRef]

22. Osono, T.; Takeda, H. Comparison of litter decomposing ability among diverse fungi in a cool temperate deciduous forest in Japan. Mycologia 2002, 94, 421-427. [CrossRef] [PubMed]

23. Osono, T. Colonization and succession of fungi during decomposition of Swida controversa leaf litter. Mycologia 2005, 97, 589-597. [CrossRef] [PubMed]

24. Song, F.; Tian, X.; Fan, X.; He, X. Decomposing ability of filamentous fungi on litter is involved in a subtropical mixed forest. Mycologia 2010, 102, 20-26. [CrossRef] [PubMed]

25. $\mathrm{Xu}, \mathrm{J}$. Invited review: Microbial ecology in the age of genomics and metagenomics: Concepts, tools, and recent advances. Mol. Ecol. 2006, 15, 1713-1731. [CrossRef]

26. Cuadros-Orellana, S.; Leite, L.R.; Smith, A.; Medeiros, J.D.; Badotti, F.; Fonseca, P.L.; Vaz, A.B.; Oliveira, G.; Góes-Neto, A. Assessment of fungal diversity in the environment using metagenomics: A decade in review. Fungal Genom. Biol. 2013, 3, 1. [CrossRef]

27. Daniel, R. The metagenomics of soil. Nat. Rev. Microbiol. 2005, 3, 470-478. [CrossRef]

28. Schmidt, P.-A.; Bálint, M.; Greshake, B.; Bandow, C.; Römbke, J.; Schmitt, I. Illumina metabarcoding of a soil fungal community. Soil Biol. Biochem. 2013, 65, 128-132. [CrossRef]

29. Buee, M.; Reich, M.; Murat, C.; Morin, E.; Nilsson, R.H.; Uroz, S.; Martin, F. 454 Pyrosequencing analyses of forest soils reveal an unexpectedly high fungal diversity. New Phytol. 2009, 184, 449-456. [CrossRef]

30. Urbina, H.; Scofield, D.G.; Cafaro, M.; Rosling, A. DNA-metabarcoding uncovers the diversity of soil-inhabiting fungi in the tropical island of Puerto Rico. Mycoscience 2016, 57, 217-227. [CrossRef]

31. Hoppe, B.; Krüger, D.; Kahl, T.; Arnstadt, T.; Buscot, F.; Bauhus, J.; Wubet, T. A pyrosequencing insight into sprawling bacterial diversity and community dynamics in decaying deadwood logs of Fagussylvatica and Piceaabies. Sci. Rep. 2015, 5, 9456. [CrossRef]

32. Purahong, W.; Arnstadt, T.; Kahl, T.; Bauhus, J.; Kellner, H.; Hofrichter, M.; Krüger, D.; Buscot, F.; Hoppe, B. Are correlations between deadwood fungal community structure, wood physico-chemical properties and lignin-modifying enzymes stable across different geographical regions? Fungal. Ecol. 2016, 22, 98-105. [CrossRef]

33. Parfitt, D.; Hunt, J.; Dockrell, D.; Rogers, H.J.; Boddy, L. Do all trees carry the seeds of their own destruction? PCR reveals numerous wood decay fungi latently present in sapwood of a wide range of angiosperm trees. Fungal. Ecol. 2010, 3, 338-346. [CrossRef] 
34. Purahong, W.; Wubet, T.; Lentendu, G.; Schloter, M.; Pecyna, M.J.; Kapturska, D.; Hofrichter, M.; Kruger, D.; Buscot, F. Life in leaf litter: Novel insights into community dynamics of bacteria and fungi during litter decomposition. Mol. Ecol. 2016, 25, 4059-4074. [CrossRef] [PubMed]

35. Zhang, N.L.; Li, Y.N.; Wubet, T.; Bruelheide, H.; Liang, Y.; Purahong, W.; Buscot, F.; Ma, K.P. Tree species richness and fungi in freshly fallen leaf litter: Unique patterns of fungal species composition and their implications for enzymatic decomposition. Soil. Biol. Biochem. 2018, 127, 120-126. [CrossRef]

36. Chen, L.; Xiang, W.; Wu, H.; Ouyang, S.; Lei, P.; Hu, Y.; Ge, T.; Ye, J.; Kuzyakov, Y. Contrasting patterns and drivers of soil fungal communities in subtropical deciduous and evergreen broadleaved forests. Appl. Microbiol. Biot. 2019, 103, 5421-5433. [CrossRef]

37. Morrison, E.W.; Pringle, A.; van Diepen, L.T.; Grandy, A.S.; Melillo, J.; Frey, S.D. Warming alters fungal communities and litter chemistry with implications for soil carbon stocks. Soil Biol. Biochem. 2019, 132, 120-130. [CrossRef]

38. Palozzi, J.E.; Lindo, Z. Are leaf litter and microbes team players? Interpreting home-field advantage decomposition dynamics. Soil Biol. Biochem. 2018, 124, 189-198. [CrossRef]

39. Purahong, W.; Wubet, T.; Lentendu, G.; Hoppe, B.; Jariyavidyanont, K.; Arnstadt, T.; Baber, K.; Otto, P.; Kellner, H.; Hofrichter, M. Determinants of deadwood-inhabiting fungal communities in temperate forests: Molecular evidence from a large scale deadwood decomposition experiment. Front. Microbiol. 2018, 9, 2120. [CrossRef]

40. Wang, J.; You, Y.; Tang, Z.; Liu, S.; Sun, O.J. Variations in leaf litter decomposition across contrasting forest stands and controlling factors at local scale. J. Plant. Ecol. 2015, 8, 261-272. [CrossRef]

41. Association, A.W.P. Book of Standards; AWPA: Birmingham, AL, USA, 2017.

42. De Gannes, V.; Eudoxie, G.; Hickey, W.J. Insights into fungal communities in composts revealed by 454-pyrosequencing: Implications for human health and safety. Front. Microbiol. 2013, 4, 164. [CrossRef]

43. Palmer, J.M.; Jusino, M.A.; Banik, M.T.; Lindner, D.L. Non-biological synthetic spike-in controls and the AMPtk software pipeline improve mycobiome data. Peerj 2018, 6, e4925. [CrossRef] [PubMed]

44. Edgar, R.C. Search and clustering orders of magnitude faster than BLAST. Bioinformatics 2010, 26, $2460-2461$. [CrossRef] [PubMed]

45. Blaxter, M.; Mann, J.; Chapman, T.; Thomas, F.; Whitton, C.; Floyd, R.; Abebe, E. Defining operational taxonomic units using DNA barcode data. Philos. Trans. R. Soc. B Biol. Sci. 2005, 360, 1935-1943. [CrossRef] [PubMed]

46. Edgar, R.C.; Flyvbjerg, H. Error filtering, pair assembly and error correction for next-generation sequencing reads. Bioinformatics 2015, 31, 3476-3482. [CrossRef] [PubMed]

47. Schloss, P.D. Application of a Database-Independent Approach to Assess the Quality of Operational Taxonomic Unit Picking Methods. mSystems 2016, 1, e00027-16. [CrossRef]

48. Abarenkov, K.; Henrik Nilsson, R.; Larsson, K.H.; Alexander, I.J.; Eberhardt, U.; Erland, S.; Høiland, K.; Kjøller, R.; Larsson, E.; Pennanen, T. The UNITE database for molecular identification of fungi-recent updates and future perspectives. New Phytol. 2010, 186, 281-285. [CrossRef]

49. McCune, B.; Mefford, M. Multivariate Analysis of Ecological Data, Version 3.0; MjM Software: Gleneden Beach, OR, USA, 1997.

50. Dufrêne, M.; Legendre, P. Species assemblages and indicator species: The need for a flexible asymmetrical approach. Ecol. Monogr. 1997, 67, 345-366. [CrossRef]

51. McCune, B.; Grace, J.B.; Urban, D.L. Analysis of Ecological Communities; MjM Software Design: Gleneden Beach, OR, USA, 2002; Volume 28.

52. Nguyen, N.H.; Song, Z.; Bates, S.T.; Branco, S.; Tedersoo, L.; Menke, J.; Schilling, J.S.; Kennedy, P.G. FUNGuild: An open annotation tool for parsing fungal community datasets by ecological guild. Fungal. Ecol. 2016, 20, 241-248. [CrossRef]

53. Clausen C, A. Biodeterioration of wood. In Wood Handbook: Wood as an Engineering Material: Chapter 14. Centennial ed. General Technical Report FPL; GTR-190: Madison, WI, USA, 2010; Volume 190, pp. 14.1-14.16.

54. Morris, P. Understanding Biodeterioration of Wood in Structures; ForIntek Canada Corp.: Vancouver, BC, Canada, 1998. Available online: http://cwc.ca/wp-content/uploads/aboutdecay-biodeterioration.pdf (accessed on 30 June 2016).

55. Zabel, R.A.; Morrell, J.J. Wood microbiology: Decay and Its Prevention; Academic Press: Cambridge, MA, USA, 2012. 
56. Viitanen, H.; Vinha, J.; Salminen, K.; Ojanen, T.; Peuhkuri, R.; Paajanen, L.; Lähdesmäki, K. Moisture and bio-deterioration risk of building materials and structures. J. Build. Phys. 2010, 33, 201-224. [CrossRef]

57. Meyer, L.; Brischke, C. Fungal decay at different moisture levels of selected European-grown wood species. Int. Biodeterior. Biodegrad. 2015, 103, 23-29. [CrossRef]

58. Zelinka, S.; Ringman, R.; Pilgård, A.; Thybring, E.; Jakes, J.; Richter, K. The role of chemical transport in the brown-rot decay resistance of modified wood. Int. Wood Prod. J. 2016, 7, 66-70. [CrossRef]

59. Schwarze, F.W. Wood decay under the microscope. Fungal Biol. Rev. 2007, 21, 133-170. [CrossRef]

60. Goodell, B.; Qian, Y.; Jellison, J. Fungal Decay of Wood: Soft Rot_Brown Rot-White Rot; ACS Publications: Washington, DC, USA, 2008.

61. Strickland, M.S.; Osburn, E.; Lauber, C.; Fierer, N.; Bradford, M.A. Litter quality is in the eye of the beholder: Initial decomposition rates as a function of inoculum characteristics. Funct. Ecol. 2009, 23, 627-636. [CrossRef]

62. Melillo, J.M.; Aber, J.D.; Muratore, J.F. Nitrogen and lignin control of hardwood leaf litter decomposition dynamics. Ecology 1982, 63, 621-626. [CrossRef]

63. Rihani, M.; Kiffer, E.; Botton, B. Decomposition of Beech Leaf-Litter by Microflora and Mesofauna.1. In-Vitro Action of White-Rot Fungi on Beech Leaves and Foliar Components. Eur. J. Soil. Biol. 1995, 31, 57-66.

64. Taylor, B.R.; Parkinson, D.; Parsons, W.F. Nitrogen and lignin content as predictors of litter decay rates: A microcosm test. Ecology 1989, 70, 97-104. [CrossRef]

65. Allegrucci, N.; Bucsinszky, A.M.; Arturi, M.; Cabello, M.N. Communities of anamorphic fungi on green leaves and leaf litter of native forests of Scutia buxifolia and Celtis tala: Composition, diversity, seasonality and substrate specificity. Rev. Iberoam. Micol. 2015, 32, 71-78. [CrossRef]

66. Aponte, C.; Garcia, L.V.; Maranon, T.; Gardes, M. Indirect host effect on ectomycorrhizal fungi: Leaf fall and litter quality explain changes in fungal communities on the roots of co-occurring Mediterranean oaks. Soil. Biol. Biochem. 2010, 42, 788-796. [CrossRef]

67. Gulis, V.; Suberkropp, K. Interactions between stream fungi and bacteria associated with decomposing leaf litter at different levels of nutrient availability. Aquat. Microb. Ecol. 2003, 30, 149-157. [CrossRef]

68. Voriskova, J.; Baldrian, P. Fungal community on decomposing leaf litter undergoes rapid successional changes. ISME J. 2013, 7, 477-486. [CrossRef]

69. Song, Z.; Kennedy, P.G.; Liew, F.J.; Schilling, J.S. Fungal endophytes as priority colonizers initiating wood decomposition. Funct. Ecol. 2017, 31, 407-418. [CrossRef]

70. Albrectsen, B.R.; Siddique, A.B.; Decker, V.H.G.; Unterseher, M.; Robinson, K.M. Both plant genotype and herbivory shape aspen endophyte communities. Oecologia 2018, 187, 535-545. [CrossRef] [PubMed]

71. Guerreiro, M.A.; Brachmann, A.; Begerow, D.; Persoh, D. Transient leaf endophytes are the most active fungi in 1-year-old beech leaf litter. Fungal Divers. 2018, 89, 237-251. [CrossRef]

72. Koivusaari, P.; Tejesvi, M.V.; Tolkkinen, M.; Markkola, A.; Mykra, H.; Pirttila, A.M. Fungi Originating From Tree Leaves Contribute to Fungal Diversity of Litter in Streams. Front. Microbiol. 2019, 10. [CrossRef] [PubMed]

73. Osono, T. Phyllosphere fungi on leaf litter of Fagus crenata: Occurrence, colonization, and succession. Can. J. Bot. 2002, 80, 460-469. [CrossRef]

74. Prakash, C.P.; Thirumalai, E.; Rajulu, M.B.G.; Thirunavukkarasu, N.; Suryanarayanan, T.S. Ecology and diversity of leaf litter fungi during early-stage decomposition in a seasonally dry tropical forest. Fungal. Ecol. 2015, 17, 103-113. [CrossRef]

75. Osono, T. Ecology of ligninolytic fungi associated with leaf litter decomposition. Ecol. Res. 2007, $22,955-974$. [CrossRef]

76. Yelle, D.J.; Wei, D.; Ralph, J.; Hammel, K.E. Multidimensional NMR analysis reveals truncated lignin structures in wood decayed by the brown rot basidiomycete Postia placenta. Environ. Microbiol. 2011, 13, 1091-1100. [CrossRef]

77. Fernandez, C.W.; Kennedy, P.G. Revisiting the 'Gadgil effect': Do interguild fungal interactions control carbon cycling in forest soils? New. Phytol. 2016, 209, 1382-1394. [CrossRef]

78. Yang, N.; Butenschoen, O.; Rana, R.; Kohler, L.; Hertel, D.; Leuschner, C.; Scheu, S.; Polle, A.; Pena, R. Leaf litter species identity influences biochemical composition of ectomycorrhizal fungi. Mycorrhiza 2019, 29, 85-96. [CrossRef]

79. Clausen, C.A.; Lindner, D.L. Shading aboveground L-joint and lap-joint tests: Comparison of white pine and sugar maple test assemblies. For. Prod. J. 2011, 61, 265-269. [CrossRef] 
80. Jenssen, K. Decay of external woodwork caused by Dacrymyces stillatus. In Proceedings of K. M. Jenssen, Proc. NIF Internat. Symp. "Degradation of Painted Wood by Fungi"; Copenhagen: Copenhagen, Sweden, 1989; pp. 11-12.

81. Schmidt, O. Indoor wood-decay basidiomycetes: Damage, causal fungi, physiology, identification and characterization, prevention and control. Mycol. Prog. 2007, 6, 261. [CrossRef]

82. Gabriel, J.; Švec, K. Occurrence of indoor wood decay basidiomycetes in Europe. Fungal Biol. Rev. 2017, 31, 212-217. [CrossRef]

83. Kirker, G.T.; Bishell, A.B.; Jusino, M.A.; Palmer, J.M.; Hickey, W.J.; Lindner, D.L. Amplicon-Based Sequencing of Soil Fungi from Wood Preservative Test Sites. Front. Microbiol. 2017, 8. [CrossRef]

84. Barroetaveña, C.; Cázares, E.; Rajchenberg, M. Ectomycorrhizal fungi associated with ponderosa pine and Douglas-fir: A comparison of species richness in native western North American forests and Patagonian plantations from Argentina. Mycorrhiza 2007, 17, 355-373. [CrossRef]

85. Unterseher, M.; Jumpponen, A.; Opik, M.; Tedersoo, L.; Moora, M.; Dormann, C.F.; Schnittler, M. Species abundance distributions and richness estimations in fungal metagenomics-lessons learned from community ecology. Mol. Ecol. 2011, 20, 275-285. [CrossRef]

86. Tedersoo, L.; Smith, M.E. Lineages of ectomycorrhizal fungi revisited: Foraging strategies and novel lineages revealed by sequences from belowground. Fungal. Biology. Rev. 2013, 27, 83-99. [CrossRef]

87. Colpaert, J.V. Heavy metal pollution and genetic adaptations in ectomycorrhizal fungi. In British Mycological Society Symposia Series; Elsevier: London, UK, 2008; pp. 157-173.

88. Huang, Y.; Kaneko, N.; Nakamori, T.; Miura, T.; Tanaka, Y.; Nonaka, M.; Takenaka, C. Radiocesium immobilization to leaf litter by fungi during first-year decomposition in a deciduous forest in Fukushima. J. Environ. Radioactiv. 2016, 152, 28-34. [CrossRef]

89. Johnson, N.C.; Angelard, C.; Sanders, I.R.; Kiers, E.T. Predicting community and ecosystem outcomes of mycorrhizal responses to global change. Ecol. Lett. 2013, 16, 140-153. [CrossRef]

90. Warcup, J. Occurrence of ectomycorrhizal and saprophytic discomycetes after a wild fire in a eucalypt forest. Mycol. Res. 1990, 94, 1065-1069. [CrossRef]

91. Purahong, W.; Lerstaveesin, P.; Ampornpan, L.A. Succession of Fungi Associated with Decomposition of Leaf Litter in Tropical Evergreen Forest (North-Eastern Thailand). Pol. J. Ecol. 2010, 58, 569-576.

92. Purahong, W.; Pietsch, K.A.; Bruelheide, H.; Wirth, C.; Buscot, F.; Wubet, T. Potential links between wood-inhabiting and soil fungal communities: Evidence from high-throughput sequencing. MicrobiologyOpen 2019, 8, e00856. [CrossRef] [PubMed]

93. Råberg, U.; Terziev, N.; Daniel, G. Degradation of Scots pine and beech wood exposed in four test fields used for testing of wood preservatives. Int. Biodeterior. Biodegrad. 2013, 79, 20-27. [CrossRef]

94. Di Marino, E.; Scattolin, L.; Bodensteiner, P.; Agerer, R. Sistotrema is a genus with ectomycorrhizal speciesconfirmation of what sequence studies already suggested. Mycol. Prog. 2008, 7, 169-176. [CrossRef]

95. Potvin, L.R.; Richter, D.L.; Jurgensen, M.F.; Dumroese, R.K. Association of Pinus banksiana Lamb. and Populus tremuloides Michx. seedling fine roots with Sistotrema brinkmannii (Bres.) J. Erikss.(Basidiomycotina). Mycorrhiza 2012, 22, 631-638. [CrossRef]

96. LINDAHL, B.; Stenlid, J.; Olsson, S.; Finlay, R. Translocation of 32 P between interacting mycelia of a wood-decomposing fungus and ectomycorrhizal fungi in microcosm systems. New Phytol. 1999, 144, 183-193. [CrossRef]

97. Lindahl, B.D.; Tunlid, A. Ectomycorrhizal fungi-potential organic matter decomposers, yet not saprotrophs. New Phytol. 2015, 205, 1443-1447. [CrossRef]

98. Toljander, Y.K.; Lindahl, B.D.; Holmer, L.; Högberg, N.O. Environmental fluctuations facilitate species co-existence and increase decomposition in communities of wood decay fungi. Oecologia 2006, 148, 625-631. [CrossRef]

99. Smith, G.R.; Finlay, R.D.; Stenlid, J.; Vasaitis, R.; Menkis, A. Growing evidence for facultative biotrophy in saprotrophic fungi: Data from microcosm tests with 201 species of wood-decay basidiomycetes. New Phytol. 2017, 215, 747-755. [CrossRef]

100. Baldrian, P. Forest microbiome: Diversity, complexity and dynamics. FEMS Microbiol. Rev. 2017, 41, $109-130$. [CrossRef] 
101. Baldrian, P.; Kolařík, M.; Štursová, M.; Kopecký, J.; Valášková, V.; Větrovský, T.; Žifčáková, L.; Šnajdr, J.; Rídl, J.; Vlček, Č. Active and total microbial communities in forest soil are largely different and highly stratified during decomposition. ISME J. 2012, 6, 248-258. [CrossRef] [PubMed]

102. Milo, A.M. Drivers of Community Composition in Wood-Inhabiting Fungi and Implications for Wood Decay in Temperate Forests; The George Washington University: Washington, DC, USA, 2018.

103. Austin, A.T.; Vivanco, L.; González-Arzac, A.; Pérez, L.I. There's no place like home? An exploration of the mechanisms behind plant litter-decomposer affinity in terrestrial ecosystems. New Phytol. 2014, 204, 307-314. [CrossRef] [PubMed]

(C) 2020 by the authors. Licensee MDPI, Basel, Switzerland. This article is an open access article distributed under the terms and conditions of the Creative Commons Attribution (CC BY) license (http://creativecommons.org/licenses/by/4.0/). 